\title{
Correction to: The relationships between paired associate learning and Chinese word writing in kindergarten children
}

\author{
Catrina Liu $^{1}$ (D) Kevin Kien Hoa Chung ${ }^{1}$ (D)
}

Published online: 1 April 2021

(c) Springer Nature B.V. 2021

\section{Correction to: Reading and Writing https://doi.org/10.1007/s11145-021-10138-5}

In the original publication of the article the first author name was published with a typo. This has been corrected with this Correction.

The original article has been corrected.

Publisher's Note Springer Nature remains neutral with regard to jurisdictional claims in published maps and institutional affiliations.

The original article can be found online at https://doi.org/10.1007/s11145-021-10138-5.

Catrina Liu

catrina0119@gmail.com

1 Department of Early Childhood Education, D4-1/F-35, The Education University of Hong Kong, 10 Lo Ping Road, Tai Po, New Territories, Hong Kong, China 